\title{
A szuverén alapok jogi háttere és nemzetgazdasági szerepvállalása
}

\author{
szuverén alap - pénzpiac - nemzeti vagyon - Magyar Nemzeti Bank
}

A jövő nemzedékeinek jóléte, valamint az államok és nemzetek jövőképében lényeges helyet elfoglaló stratégiai célok fontos eszközei a szuverén alapok. Ezek a jogi és gazdasági szempontból egyaránt rendkívül érdekes intézmények már hoszszú ideje müködnek, mégis viszonylag kevéssé ismertek, összehasonlítva például a fedezeti alapok (hedge fundok) sztármenedzsereinek ismertségével. Ez bizonyos szempontból érthető is, hiszen utóbbiak a befektetőik számára mesés vagyonokat keresnek - de ezt rövid távon teszik, rendkívüli kockázatok felvállalása mellett. Ugyanakkor a jövő generációinak boldogulásához és a hosszú távú célok megvalósításához az elöbbiek - vagyis a szuverén alapok - járulhatnak hozzá jelentősebb mértékben. $E$ tanulmány szerzője éppen emiatt érzi úgy, hogy tanulmánya - „Pro Futuro" - hozzájárulhat ahhoz, hogy a szuverén alapok alkalmazásának elöremutató nemzetközi példáit hazai viszonyok közt is népszerüsítse. Eközben összehasonlító jogi szemléletben kerül sor az intézmény nemzetközi szabályozásának elemzésére, majd annak összevetésére a hazai szabályozási környezettel.

A szuverén alapok olyan befektetési alapok, ${ }^{1}$ amelyeket az államok (vagy az államok jegybankjai) hoznak létre és müködtetnek. A szuverén alapok a 2007-2008-as pénzügyi válság idején kerültek elöször reflektorfénybe azzal, hogy fehér lovagként ${ }^{2}$ avatkoztak be és mentették meg az amerikai és európai tőkepiacok néhány emblematikus vállalatát attól, hogy csődbe menjenek. Ezt követően 2016-ban ismét az érdeklődés középpontjába kerültek mint az állami intézményi alapok sajátos formái. Napjainkban ugyanis a szuverén alapok jelentős portfólióátrendezésre kényszerülhetnek, amennyiben a kőolaj ára ismét a 30-40 USD közötti árfolyamszintre sülylyedne, és ott tartósan rögzülne is. Ebben az esetben ugyanis akár 404 milliárd USD

* Dr. Kecskés András egyetemi docens, Pécsi Tudományegyetem Állam- és Jogtudományi Kar Gazdasági és Kereskedelmi Jogi Tanszék, kecskes.andras@ajk.pte.hu. A tanulmány a Magyar Tudományos Akadémia Bolyai János Kutatási Ösztöndíjának támogatásával készült.

1 A befektetési alapok olyan intézményi befektetők, melyek magán- és intézményi befektetők megtakaritásait portfólióelven megosztva kezelik. Az alapkezelö által meghatározott befektetési politika ellenőrzését a független letétkezelö végzi azzal, hogy felügyeli, hogy a befektetés a meghatározott eszközosztályban és azon belül is kibocsátói limitek betartásával történjen.

2 Fehér lovagnak nevezik a felvásárlások során a baráti kezet nyújtó felvásárló társaságot. Ezzel az ellenséges felvásárló (fekete lovag) által indított tranzakciót hiúsítja meg. Hatására többnyire a társaság vezetése is a helyén marad. 
tőkét is kivonhatnak a globális részvénypiacokról az állami alapok befektetői. ${ }^{3}$ Ennek az az oka, hogy az alapok felett tulajdonosi jogokat gyakorló államok költségvetéseinek szüksége lehet ezekre a forrásokra, az alacsony kőolajár miatt kieső bevételek pótlása érdekében. Másrészt a szuverén alapok piaci helyzetét ${ }^{4}$ jelentősen átalakíthatja, ha Szaúd-Arábia - a várakozásokkal összhangban - 2017-ben létrehozza a legnagyobb (kétezer milliárd USD volumenü) alapját. ${ }^{5}$ Sőt ezzel a tranzakcióval a globális - harmincezer milliárd USD volumenü - tökepiacon is közel $20 \%$-os arányban szereznének részesedést a szuverén alapok.

A témakör Magyarországon is különösen aktuális kérdéseket vethet fel, amennyiben figyelembe vesszük, hogy az utóbbi két évben a Magyar Nemzeti Bank (MNB) monetáris politikájának eredményeképp ${ }^{6}$ jelentős pénzügyi tartalék képződött, melynek lehetséges (és eredményes), de eddig még Magyarországon nem alkalmazott felhasználási módja lehetne egy - a jegybank által kezelt - szuverén alap létrehozása.

A jogi szabályozási háttér kérdései a befektetési alapok esetén is meghatározók. Ugyanakkor a szuverén alapok kezelésének és müködtetésének területén a jogi szabályozás jelentősége amiatt nyer az előzőnél is nagyobb hangsúlyt, mert az általuk kezelt források közpénzböl származnak, és felettük az állam közvetett irányítási jogokat gyakorol, mégpedig a közjogi szervek (Kormány, Országgyülés) számára a jegybanktörvény által keletkeztetett irányítási jogokon keresztül.

Magyarországon a jegybank, az állam és a kormányzat kapcsolata tekintetében nehéz megfelelő elhatárolásokat tenni pusztán jogszabályi rendelkezésekre támaszkodva. Ugyanis a jogszabályok alapján csak közvetve, ezt csak logikai öszszefüzésük után lehet egyáltalán megkísérelni. Eltérő logikai láncolat esetében így akár lényegesen eltérő eredményt jelentő álláspontra is lehet jutni. A továbbiakban kísérletet teszünk azon jogszabályok értelmezésére, melyek nem a szuverén alapok szabályozására jöttek létre, de azokra hatást gyakorolnak. Tulajdonképpen szabályozás hiányában keressük a jelenlegi jogszabályok adta keretrendszert egy szuverén alap számára. A részvénytársasági formában müködő Magyar Nemzeti Bank (MNB) felett a 2013. évi CXXXIX. törvény 5. § (1) bekezdése alapján az állam mint részvénytulajdonos gyakorolja a tulajdonosi jogokat. A 2013. évi CXXXIX. törvény 1 . §

3 http://www.portfolio.hu/finanszirozas/bajban_az_olajnagyhatalmak_repul_a_csaladi_ezust.227586.html (2016. 05. 11.).

4 A 2016. februári adatok (IWGSF-adat) alapján 7,088 ezer milliárd USA-dollárt kezeltek a szuverén alapok. Lásd http://www.swfinstitute.org/sovereign-wealth-fund-rankings/ (2016. 05. 12.).

5 http://www.bloomberg.com/news/articles/2016-04-01/saudi-arabia-plans-2-trillion-megafund-to-dwarf-allits-rivals (2016. 05. 12.).

6 Az MNB 2013. évi eredménye 26,3 milliárd forint nyereség volt, míg a devizaárfolyam-változásból származó eredménye 200,3 milliárd forint volt ugyanebben az évben. Az MNB 2014. évi eredménye már 27,4 milliárd HUF nyereség volt, a devizaárfolyam-változásból származó eredmény ekkor 511 milliárd forint összeget ért el. 2015-ben az MNB eredménye 95 milliárd forint volt, ebből 50 milliárd forint osztalék formájában a költségvetésbe befizetésre kerül. Az osztalékfizetést követően 2016-ra az MNB eredménytartaléka így 108 milliárd forintra csökkent. A fentiek alapján látható, hogy 2013-14-ben összesen 53,7 milliárd forint nettó nyeresége volt a jegybanknak, a devizaárfolyam-változásból származó eredmény pedig összesen 711,3 milliárd forint összegű volt ugyanezen időszakban. Az MNB döntése alapján ez utóbbi eredmény terhére, de az eredménytartalékkal szemben elszámolva került a 260 milliárd forint az alapítványokba. 
(2) bekezdése kimondja, hogy a Kormány és más szervezetek nem befolyásolják a Magyar Nemzeti Bankot (MNB) tevékenysége során. A tulajdonosi jogok gyakorlásakor az államot az államháztartásért felelős miniszter képviseli, aki kormánytag. Ezért a Kormány - közvetetten - meghatározó befolyást gyakorol a Magyar Nemzeti Bank (MNB) felett, viszont az egyes jegybanki szervek tagjait a Kormány közvetlenül nem utasíthatja. A részvényes képviseletében ugyanis fontos döntések születhetnek a 2013. évi CXXXIX. törvény 6 . § (1) bekezdése alapján a létesítő okiratról és annak módosításáról, illetve egyéb lényeges kérdésekröl. Emellett a Magyar Nemzeti Bank (MNB) elnökének személyére a miniszterelnök tesz javaslatot, a 2013. évi CXXXIX. törvény $10 . \S(1)$ bekezdése szerint. A Magyar Nemzeti Bank elnöke szóbeli és írásbeli beszámolási kötelezettséggel tartozik az Országgyülésnek a 2013. évi CXXXIX. törvény 2. §-a, valamint 131. § (1)-(2) bekezdése értelmében. A 2013. évi CXXXIX. törvény 9 . $\S(4)$ bekezdés $c$ ) pontja pedig a monetáris tanács tagjai egy részének megválasztását az Országgyülés hatáskörébe utalja.

Mivel a szuverén alapok müködésük során a jegybank irányítása alatt, annak egyes stratégiai céljait valósítják meg, így a fentiek alapján világosan látható, hogy az állami és a kormányzati szféra a szuverén alapok felett is gyakorol befolyást, mely azonban a jogszabályok értelmében inkább tulajdonosi, mintsem irányítási jogokra terjed ki.

A jogszabályi háttér közjogi vetületei, a gazdasági hatékonyság tőkepiaci jogi alapjai, valamint a menedzsment társasági jogi kötődése, a jogi kérdésfelvetések és megoldások nemzetközi viszonylatban is széles palettáját tárja az olvasó elé, s e tanulmány csupán ezek egy részének megválaszolására vállalkozhat, elörebocsátva, hogy a jövöben számos újabb kérdés merülhet fel az állami/kormányzati - tehát szuverén - alapkezelési tevékenységgel kapcsolatban.

A legérdekesebb magyar jogi kérdésfelvetés éppen azzal áll összefüggésben, hogy a szuverén alapok működéséről, ellentétben több más ország jogi szabályozásával, külön jogszabály nem rendelkezik. Emiatt a jövőben potenciálisan alapítható magyar szuverén alap(ok) csak a vonatkozó gazdasági közjogi és az alapkezelésre vonatkozó tőkepiaci jogi szabályok határmezsgyéjén lavírozhatnak, de semmilyen konkrét jogszabályi rendelkezés nem specifikálja sajátos jogi státuszukat és nem alkot többletkövetelményeket müködésükre nézve.

A fentieken túlmenően annak megválaszolására is kísérletet teszünk, hogy a szuverén alapok állami tulajdonosi szempontjai hogyan és milyen mértékben egyeztethetök össze az intézményi befektetői szerepkörrel? Lényeges kérdés az is, hogy az egyes eltérő nemzetállami érdekek - mind befektetői és célországi vonatkozásban - milyen szabályozási megoldásokkal hangolhatók össze?

\section{A szuverén alapok meghatározása}

A szuverén alapok fogalmi meghatározásakor érdemes előzetesen definiálni, hogy mennyiben élveznek szuverenitást a szó hagyományos értelmében és menynyiben tekinthetők befektetési alapoknak a tradicionális befektetésialap-fogalom tekintetében. 


\subsection{Mennyiben mutatnak szuverén vonásokat a szuverén alapok?}

A szuverenitás legkiterjedtebb jelentése szerint olyan állapotra utal, melynek alanya nincs alávetve más személy vagy csoport hatalmának. Jean Bodin francia jogtudós, a szuverenitás tanának kimunkálója úgy tartotta, hogy a szuverenitás nem más, mint a fejedelem által gyakorolt teljhatalom. ${ }^{7}$ Thomas Hobbes angol filozófus is hasonlóképp vélekedett a szuverénről, az ő megfogalmazása szerint „[a]z egy és oszthatatlan szuverenitás megtestesítője az államfö". ${ }^{8}$ John Austin, a 19. századi angol jogfilozófus a szuverén fogalmát olyan személyként vagy csoportként (testületként) definiálta, amely a „társadalom túlnyomó többségének engedelmességét élvezi”, valamint „nem tartozik engedelmességgel más evilági hatalomnak”. ${ }^{9}$ Figyelemre méltó Carl Menger ${ }^{10}$ nézete a szuverenitásról, amely szerint szuverén az, aki szükség esetén a jogszabályokkal szemben is képes érvényesíteni az akaratát. $\mathrm{E}$ nézőpont már előrevetíti az állami szuverenitás-tanának a meghaladását, amelynek egyik iránya Hugo Krabbe jogszuverenitás tanában csúcsosodott ki. Krabbe szerint a szuverenitás személytelen hatalom, amely a jogszabályokban rejlik. Ez tehát azt jelenti, hogy a szuverenitás nem az egyes személyek akaratán nyugszik, hanem „az emberek lelkierején megnyilvánuló jogtudaton”, ${ }^{11}$ emiatt a jogot tekinti a legfőbb szuverénnek. Végezetül fontosnak tartjuk felidézni Visegrády Antal professzor álláspontját a szuverenitás lényegéről, amely szerint a szuverenitás „az államhatalom nélkülözhetetlen ismérve, annak politikai és jogi kifejeződése". ${ }^{12}$

Ennek értelmében a szuverén alap - elnevezésével ellentétben - mégsem szuverén a szó állambölcseleti értelmében, de tény, hogy a tulajdonosi jogokat és az irányítási és ellenőrzési jogok egy részét a szuverén államot képviselő kormányzati szervek - Magyarországon akár az Országgyülés - gyakorolják felette. A szupranacionális szervezetek viszonylatában értelmezhető állami szuverenitási korlátok persze ebben az esetben jelentős tényezővé válnak (például az európai uniós tagságból fakadó jogharmonizációs kötelezettség), hiszen a befektetési alapok jogi szabályozási hátterének a szupranacionális jog képezi az alapját. Ilyennek tekinthető az $E U$ Alternative Investment Fund Management direktívája, amely az alternatív befektetési alapok kezelésének európai szabályait fekteti le. E szabályokhoz képest a nemzeti (tagállami jogok) nem állapíthatnak meg enyhébb kritériumokat (például a tőkekövetelmények tekintetében), így a szuverén alapokra vonatkozó szabályok megállapításakor az állam sem a klasszikus értelemben vett szuverenitás legkiterjedtebb keretei között alkot jogszabályt. Ebből adódóan úgy véljük, hogy a szuverén alap kifejezés használata nem a legpontosabb, bizonyos országok tekintetében szerencsésebb lenne állami alapoknak nevezni azokat.

7 Visegrády Antal: A jog-és állambölcselet alapjai. Dialóg Campus, Budapest-Pécs, 2001, 229-232.

8 VISEGRÁdY: i. m., 229-232.

9 Bıx, Brian: John Austin. In: Stanford Encyclopedia of Philosophy. Stanford University, 2006. Elérhető: http:// plato.stanford.edu/.

10 Carl Menger (1840-1921) közgazdász, az osztrák közgazdasági iskola egyik alapítója.

11 VISEGRÁDY: i. m., 229-232.

12 VISEGRÁDY: i. m., 232. 
Mégsem meglepő az elnevezés. Nem szabad ugyanis elfelejteni, hogy a szuverén alap kifejezést ${ }^{13}$ eredetileg az Egyesült Államokban kezdték alkalmazni, mely föderatív államként nincs olyan mértékben kitéve a szupranacionális szervezetek által diktált jogi szabályozási trendeknek, mint például az Európai Unió tagállamai.

A szuverenitás ezért a befektetési alapok viszonylatában semmiképpen sem jelentheti, hogy a szuverén alapok más alapoknál kiterjedtebb mozgásteret, kedvezőbb szabályozási környezetet vagy állami többletgaranciákat élvezhetnének. Ez teljesen ellentétes lenne a szabadpiac koncepciójával. Sokkal inkább arról van szó, hogy ezek az alapok a szuverén (elsősorban az állam) gazdasági céljainak előmozdítói.

E tanulmány a továbbiakban a szuverén alapok müködése tekintetében a szuverenitást e fent vázolt keretek között értelmezi. A szuverén alapokat a továbbiakban az alábbi szerint határozzuk meg: szuverén az alap (például az állam) célja, ha a társadalom (túlnyomó) többsége vagy egésze számára hosszabb (stratégiai távlatban) elérhetőek azok a gazdasági előnyök, amelyek költségvetési vagy gazdaságpolitikája révén elóálltak. Szuverén az alap abban a tekintetben, ha az így keletkezett forrásokat mint piaci feltételek mellett müködtetett (tehát szuverenitást nem élvező) befektetési alap kezeli, és hasznait a szuverén müködtető stratégiai céljai szerint juttatja vissza a társadalomnak.

\subsection{Mennyiben mutat befektetési alap jelleget a szuverén alap?}

A befektetési alap egy olyan pénzügyi eszköz, befektetési forma, mely a csoportos befektetési elönyeit kihasználva tökét von be nyilvános vagy zárt körben. Azzal, hogy a befektetők professzionális vagyonkezelöre bízzák a megtakarításaikat, gyakorlatilag szakértelmet vásárolnak. Ennek a szakértelemnek valós ára is létezik, ez pedig a vagyonkezelési dij. Ezt a dijat az alap kezelője a kezelt vagyonra és éves időszakra vetítve határozza meg.

Az alapkezelő az aktívan kezelt alapok portfólióját sürübben cseréli ugyanazon időszak alatt, mint egy passzívan kezelt alap esetében ez történik. A passzív alapok jellemzően egy tőzsdeindex vagy más összetett pénzügyi mutató összetételét követik le, azaz ezt a portfóliót másolják le, és csak a portfólió változásai szerint változtatnak az alapok portfólióján is.

A csoportosan kezelt vagyon a méretgazdaságosság és a portfólió diverzifikáció előnyeit is felhasználja a befektetések forgatása során. Így az alapok tulajdonosai nemcsak szélesebb körben, de kisebb megtakarításokkal nehezen (vagy egyáltalán nem) elérhető pénzügyi eszközökbe is fektethetnek alacsonyabb kockázat mellett.

A befektetési alap vagyona azonban a portfóliókezelési és bizományosi megbízásoktól eltérően elkülönül nemcsak mérleg, de jogalanyi szinten is az alapkezelő mint vagyon kezelésével megbízott személy vagyonától. Ebben a tekintetben a bizalmi vagyonkezelés egyes sajátosságait is visszatükrözi a befektetési alapok müködése. Egy önálló jogalany, a letétkezelő végzi a befektetési tevékenységek ellenőrzését. Az ellenőrzés során vétójoggal élhet, ha az adott befektetési megbízás nem felel

13 Részletesen lásd az 1.3. alfejezet első bekezdését. 
meg a befektetési alap befektetési politikájában meghatározottaknak. Az alapok jelentős részénél az adminisztratív és marketingfeladatokat is harmadik személy végzi. Azzal, hogy a vagyon elkülönítése de facto is megtörténik, a befektetők jelentős garanciát kapnak a vagyonuk megőrzésére. Így a befektetők pénze biztonságban van, de ez nem egy hozam vagy tökegarancia-intézmény, mert az alapok hozama a befektetési politikától függően változhat akár pozitív, akár negatív irányban. A hozamok könnyebb áttekintését az évesitett hozamszámítás és nettó eszközérték ${ }^{14}$ intézménye segíti.

A befektetési alap tehát alkalmas egy meghatározott vagyon elkülönített, profeszszionális kezelését biztositani megfelelö intézményi garanciát biztosítva ezzel a vagyon eredeti tulajdonosának. Ebből a szempontból tekinthető a szuverén alap is befektetési alapnak. A kezelői jogok ebben az esetben átadásra kerülnek az alapkezelő számára a befektetési politika mentén, de a tulajdonosi jogok a bizalmi vagyonkezelésnél szükebb módon értelmezhetők a vagyonkezelő vonatkozásában, mert csak és kizárólag az adott befektetési politika által meghatározott eszközosztályok keretében gyakorolhatja az alapkezelő az átruházott tulajdonosi jogokat. Ebben a viszonylatban inkább a bizalmi vagyonkezeléshez hasonlít a szuverén alap müködtetése, mert a szuverén alap is egy általa meghatározott kedvezményezetti kör számára (pl. a későbbi generációk számára) választja az alapkezelési formát és nem a - rövid vagy középtávon érvényesülő - saját céljainak a megvalósításához, ahogy azt egy befektetési alap tulajdonosa teszi.

Egy fontos különbségre külön is érdemes felhívni a figyelmet. Ez pedig a befektetési alapok passzív jellege. Míg az állam a szuverén alapok kezelése során a tulajdonosi jogait folyamatosan és aktívan gyakorolja, azaz aktív tulajdonos, addig a befektetésijegy-tulajdonosok még a képviseleti és szavazati jogaikkal sem élhetnek, hiszen a befektetési jegyeik ilyen jogokat nem testesítenek meg. A befektetési jegy tulajdonosa, amennyiben nem elégedett az alapkezelő teljesítményével, akkor csak a „lábával szavazhat”, azaz kiléphet az alapból, eladhatja befektetési jegyeit. Emiatt a befektetési alapként való müködés csak abban a kizárólagos esetben kínálhat a szuverén alapok számára alkalmas jogi formát, ha az alapkezelő az állam 100\%-os (kizárólagos) tulajdonában áll. Emiatt fontos, ahogy a nemzetközi gyakorlat visszaigazolja, hogy a szuverén alapok külön jogszabály alapján müködjenek. Amennyiben ugyanis csak a befektetési alapokra vonatkozó jogszabályok alapján létesülnének és müködnének, akkor az állam mint tulajdonos mozgástere jelentősen szükülne (például a befektetési korlátok és a közzétételi kötelezettségek miatt). Ebben a vonatkozásban érhető tetten a szuverén alapok legszuverénebb vonása: ha az általános szabályok szerint nem is, de a szuverén (tehát az állam) által alkotott speciális jogszabállyal előnyösebb szabályok szerint müködhetnek.

14 A nettó eszközérték megmutatja egy portfólió összes követeléseinek és kötelezettségeinek egy adott időpontra eső különbségét. Ez a nettó eszközérték egyegységnyi befektetésre, egy befektetési jegyre vetítve is meghatározható, ha a portfólió nettó eszközértékét elosztjuk a befektetési jegyek számával. 


\subsection{A szuverén alap fogalma}

A szuverén alapok elnevezést első alkalommal ${ }^{15}$ Andrew Rozanov ${ }^{16}$ befektetési bankár használta, és azokat az állami alapokat jelölte vele, melyek a költségvetési többletek „melléktermékeiként” jönnek létre, a kedvező makrogazdasági, kereskedelmi és fiskális egyenlegnek köszönhetően, melyek hosszú távú tervezés és költségvetési megszorítások eredményeképp alakultak ki.

Az önszabályozási mechanizmusok területén meghatározó jelentőségü International Working Group of Sovereign Funds (IWGSF) ${ }^{17}$ munkacsoport ennél egyszerübben fogalmaz. Álláspontjuk szerint a szuverén alap egy olyan speciális befektetési alap, amely felett egy állam kormánya rendelkezik. Az adott állam kormánya az alapot makrogazdasági ${ }^{18}$ célokra hozza létre. A szuverén alap pénzügyi céljai teljesítése érdekében állami eszköz- és vagyonkezelést folytat és olyan pénzügyi stratégiákat valósít meg, melyek része a külföldi pénzügyi eszközökbe történő befektetés is.

A fenti nézőpontkülönbség alapján szükségesnek véljük saját definíciónk megalkotását, hogy a továbbiakban egységes fogalmi keretek között vizsgálhassuk a szuverén alapok müködését. Álláspontunk szerint a szuverén alap a) átmeneti időszakban és korlátozott mértékben rendelkezésre álló állami forrásokat kezelö;19 b) hosszú távú nemzetgazdasági célokat megvalósító; c) saját vagyonkezelő szervezetet vagy független vagyonkezelöt alkalmazó; d) nagyobb részben az adott nemzetgazdaságon kívül pénzügyi eszközökbe fektető; e) önálló jogi személyiséggel rendelkező vagy az adott állam pénzügyminisztériumának vagy jegybankjának közvetlenül vagy közvetve alárendelt jogalany.

A továbbiakban tehát a fenti definíció alapján vesszük sorra a szuverén alapok által kezelt forrásokat, az általuk megvalósítani kívánt makrogazdasági célokat, e célok megvalósításának jogi és szervezeti formáit, valamint a megvalósítást biztosító vagyonkezelési és vagyonallokációs stratégiákat.

15 Rozanov, Andrew: Who Holds the Wealth of Nations? Central Banking Journal, 2005/5. Lásd még https:// web.archive.org/web/20080529122341/http://www.ssga.com/library/esps/Who_Holds_Wealth_of_Nations_ Andrew_Rozanov_8.15.05REVCCRI1145995576.pdf, 1. (2016. 05. 12.).

16 Andrew Rozanov befektetési bankár. Többek között a Union Bank of Switzerlandnél (UBS), a State Street Advisorsnál dolgozott és intézményi befektető ügyfelekkel foglalkozott. Jelenleg a Permal Advisory Groupnál dolgozik ügyvezető igazgatóként, és intézményi befektető ügyfeleknek hosszú távú portfólióépítéshez, kockázatkezeléshez, alternatív befektetésekhez és kis valószínűséggel bekövetkező, de nagy veszteséget okozó pénzügyi kockázatok (tail-risk) kezelésére ad tanácsokat.

17 A szuverén alapok nemzetközi munkacsoportja (International Working Group of Sovereign Funds - IWGSF) 2009-ben alakult, a Santiago Elveket elfogadják. A globális hálózat célja az együttműködés erősítése és a legjobb gyakorlatok és vállalatirányitási példák megosztása. Lásd http://www.ifswf.org/ (2016. 05. 11.).

18 A makrogazdaság egy nemzetgazdasági vagy ennél magasabb szintű gazdasági egység, ahol az egyes vállalkozások, magánszemélyek, önkormányzatok és az adott állam mint gazdasági szereplők teljesítménye aggregát, azaz összesített módon jelenik meg. Ennek következményeként az egyes szereplök teljesítménye és müködése erősítheti, de ki is olthatja egymást. A mikrogazdasági szint az egyes - önálló - gazdasági egységek szintje.

19 Példaként említhető a nyersanyagforrások bevétele azon időszakból, amikor az adott nyersanyag hosszú évtizedekre jellemző átlagára fölé emelkedik, egyes iparágak felfutásából származó átlag feletti exportárbevételből származó devizatartalék felhalmozódása vagy az állami vagyon hasznosításából származó egyéb egyszeri bevételek (privatizáció, koncesszióba adás). 


\section{A szuverén alapok történeti áttekintése}

A szuverén alapok első formái a mai fogalomhasználatunk ${ }^{20}$ szerint az 1950-es években jöttek létre. A Közel-Keleten 1953-ban alakult meg Kuvaitban a Kuwait Investment Authority (KIA), mert az olajértékesítésből származó állami bevételek ez idő szerint már forradalmi növekedést értek el. Emiatt az olajbevételek hosszú távú (stratégiai) felhasználására alakítottak ki olyan jogi megoldást, melynek alapján egy vagyonkezelő szervezet (a KIA) kezeli a kuvaiti szuverén alapokat - a Kuwait General Reserve Fundot (GRF) ${ }^{21}$ és a Kuwait Future Generation Fundot (FGF). ${ }^{22}$ Ez utóbbi alapba folyik be Kuvait éves olajbevételének 10\%-a. ${ }^{23} 2016$ februárjában összesen 593 milliárd USA-dollárt tett ki a két alap összesített tőkéje. Az alapok nemzetgazdasági súlyát jelzi, hogy az igazgatótanács elnöke a pénzügyminiszter, tagja az olajügyi miniszter, a jegybank elnöke, a pénzügyminisztérium államtitkára és további öt független szakértő. ${ }^{24}$ Közülük hárman kizárólagos tevékenységként végzik munkájukat.

1956-ban egy kis csendes-óceáni szigetállamban - Kiribatiban - alakult a világ második szuverén alapja, a Kiribati Revenue Equalisation Fund. ${ }^{25} \mathrm{Az}$ alap azzal a céllal jött létre, hogy a guanóbányászat jövedelméböl a későbbi nemzedékek is részesülhessenek. A cél megvalósult, hiszen bár a foszfát előállítására használt guanó bányászata mára rég megszünt, az alap vagyona mégis 400 millió USD-re nőtt, melynek 10\%-os hozama 2008-ban a GDP közel 16,5 százalékával ${ }^{26}$ növelte a sziget költségvetését.

A szuverén alapok létesítésének következő hulláma az 1970-80-as években a két nagy olajválság ${ }^{27}$ hatására következett be. 1973 és 1978 között az egyes olajexportáló államok olajbevételei a közel ötszörösére nőtt olajárak hatására jelentősen megugrottak. Az olajárrobbanás hatását azonban a piac nem ítélte fenntarthatónak,

20 A Texas Permanent School Fund volt az első hasonló alap, melyet 1854-ben hoztak létre 2 millió USD alaptőkével. 2016-ra az alap által kezelt töke elérte a 34,5 milliárd USD-t. Azonban mivel Texas államának olajbevételeiből építkezik az alap, nem tekinthető szuverén állam alapjának, hiszen Texas az Egyesült Államok tagállama.

${ }^{21}$ Az állami olajbevételek ebbe az alapba (GRF) folynak be. Ebböl az alapból került át az 1976-ban a később létrehozott alapba (FGF) a vagyon $50 \%$-a, és évente az olajbevételek $10 \%$-a is az alapon keresztül kerül át a másik (FGF) alapba. Évente az éves költségvetés dönt az alapból történő eszközkivonásról.

22 Az 1976-ban létrehozott alap (FGF) célja a külföldi eszközök kezelése.

23 Lásd http://www.kia.gov.kw/en/ABOUTKIA/Pages/GRF.aspx (2016. 05. 14.).

${ }^{24} \mathrm{Az}$ 1982. évi 42. törvény 3. cikkelye alapján az öt független tagból három nem viselhet más állami hivatalt, és mindegyik tagot 4 évre nevezik az Emír rendeletével (Amiri Decree).

25 http://www.economist.com/node/10533428 (2016. 05. 14.).

$26 \mathrm{http}: / /$ www.economist.com/node/10533428 (2016. 05. 14.).

27 Az első nagy olajválság 1973 októberében kezdődött az OPEC embargójával, amelynek hatására a nyersolaj ára 3 USD-röl 12 USD-re nőtt az embargó végére, 1974 márciusára. Az embargó oka az 1973-as jom kippuri háború volt. A háborúban ugyanis, miután Egyiptom és Szíria légitámadást indított Izrael ellen, az Egyesült Államok hat napon belül elkezdte fegyverekkel támogatni Izraelt. Ez volt az az esemény, amire az OPEC az embargóval reagált. Az 1979-es vagy második nagy olajválság az iráni forradalom kitörése miatt alakult ki. A világ nyersolaj-kitermelése az iráni forradalom miatt mindössze négy százalékkal csökkent, de a nyersolaj ára egy év alatt közel megduplázódott, elérve a 39,5 USD csúcsot, majd ezt követöen egy közel húszéves árfolyamesés következett be a nyersanyag árában. 
hiszen a növekedés a valóságban az OPEC ${ }^{28}$ összehangolt megállapodásainak volt köszönhetö. Amíg a 2000-es évek elején a nyersanyagárak szárnyalása adott impulzust a szuverén alapok létrejöttének, addig 2009-et követően a pénzügyi válság adott újra dinamizmust a nem nyersanyagokra alapozott, de éppen a válságok hatásait csökkenteni képes alapok számának növekedéséhez.

\section{A szuverén alapok tőkéjének forrásai}

A szuverén alapok tőkéjének lehetséges forrásait alapvetően négy egymástól jól elkülöníthető kategóriába sorolhatjuk

a) A szuverén alapok forrásainak számbavételekor első helyen állhatnak a feltárt nyersanyagok kitermelése által biztosított hasznok. Az olajkitermelő államok olajbevételei mellett a színesfém és a gyémánt kiemelkedő szerepet tölt be napjainkban, ezek a példák azonban korántsem tekinthetők kizárólagosnak. Érdekes visszásság, hogy hosszú távon a nyersanyag alapú növekedés gazdasági recessziót eredményezhet, melyet jól illusztrál a holland betegségként ${ }^{29}$ ismert kedvezőtlen hatásmechanizmus, melyet alább részletesen ismertetünk. Emiatt fontos, hogy a nyersanyag-kitermelés és értékesítés/ felhasználás útján keletkező költségvetési többlettel megfelelően - például szuverén alapok közbeiktatása útján - gazdálkodjon az állam.

Lényeges felhívni a figyelmet arra, hogy az innováció szerepe - bár nem természeti, hanem humánerőforrás gyümölcse - ugyanolyan fontos napjainkban, mint a föld méhének kincsei. Az Egyesült Államok Kalifornia és Seattle tagállamainak innovációs központjai, az innovatív alapokon újraépülö izraeli gazdaság, illetve a dél-koreai számítástechnikai innováció nemzetgazdasági súlya egytől egyig alátámasztja az innovatív ágazatok elöretörésének nemzetgazdasági szinten is leképeződő előnyeit.

b) A jelentős devizatartalékok, melyek a külkereskedelem tartós pozitív mérlegének hatására ugrásszerủen megnövekedhetnek, ragyogó lehetőséget kínálnak egy stratégiai célt szolgáló szuverén alap indulótőkéjének biztosításához. Például a Magyar Nemzeti Bank (MNB) 2012 és 2015 között folytatott devizagazdálkodási politikája miatt a korábban allokált jegybanki devizatartalékok HUF-ban felértékelődtek, amely a Magyar Nemzeti Bank (MNB) mérlegében árfolyamnyereség formájában jelentkezett.

Az így keletkezett többlet felhasználására több lehetőség is kínálkozik. Ezek egyike lehetne egy (vagy több) magyarországi szuverén alap létrehozása és müködtetése. Megalapozottan beszélhetünk több alapról, mert a szuverén alapok kezelése te-

${ }^{28}$ Az Olajexportörök Nemzetközi Szervezete (Organization of the Petroleum Exporting Countries - OPEC). A kormányközi szervezet 1960. szeptember 10. és 14. között öt ország (Irán, Irak, Kuvait, Szaúd-Arábia és Venezuela) részvételével jött létre azzal a céllal, hogy koordinálja és egyesítse a tagországok olajpolitikáját. Jelenleg tizenhárom tagja van a bécsi székhelyủ szervezetnek. A későbbiekben az alapító tagokhoz csatlakozott Algéria, Angola, Ecuador, Indonézia, Líbia, Nigéria, Katar és az Egyesült Arab Emírségek. A világ kőolajkészleteinek több mint felét ellenőrzése alatt tartja a szervezet, de a kitermelés viszonylatában ez az arány nem éri el az ötven százalékot.

29 A fogalmat az Economist brit gazdasági folyóirat vezette be 1977-ben, és a közgazdasági modellt V. Max Corden és J. Peter Neary közgazdászok 1982-ben dolgozták ki. 
rületén már nagyobb gyakorlattal rendelkező országok jellemzően belföldi és külpiacokon kereskedö - tehát legalább két - elkülönített befektetési alapot hoznak létre.

A nemzetközi tapasztalatok alapján az országok jelentős része nemcsak a devizatartalékok felértékelődéséből fakadó hasznot, de magát a devizatartalékot is szuverén alapok közbeiktatásával kezeli, mert a devizatartalékot - mint biztonsági tartalékot - nem felhasználni, hanem felhalmozni törekszik, néhány lényeges kivétel mellett, hiszen az erős valutával rendelkező országoknak (például Svájc) a devizatartalék felhalmozása egyidejüleg deficit növekedését is jelenti. Szemléletmódbeli változásnak vagyunk tanúi, hiszen korábban a jegybankok a devizatartalékra csak mint pénzeszközre (likvid eszközre) tekintettek, napjainkban azonban már mint befektetési eszközt veszik tekintetbe azokat, miáltal szerepük egyre inkább felértékelődik. ${ }^{30}$

c) A költségvetés forrásai különösen a pozitív szaldós zárszámadással végződött években lehetnek szuverén alapok forrásai. Ezek azonban a rövid, középtávú politikai ciklusok miatt csak ritkán és rövid ideig állnak rendelkezésre.

Kínában az utóbbi tíz évben a reálgazdasági fejlődés és a jelentősen exportorientált gazdasági modell nagy külkereskedelmi mérlegpozitívumot eredményezett, ami a gyakorlatban költségvetési többletben manifesztálódott. Kínában ebből a növekedésböl több szuverén alap sarjadt ki, melyek akkor is hasznot hajthatnak társadalmi szinten, ha az ország az elmúlt évtized gyakorlatától eltérően belső piaci alapokra helyezi a gazdasági súlypontjait.

Látszólag azonban a kínai alapkezelök számára kevésbé fontosak az elhatárolási szempontok, és több olyan hibrid - csak elemeiben szuverén - alapot is müködtetnek, melyek kizárólag a belső piac fejlesztését célozzák, és ezen belül is egyes ágazatok és régiók fejlesztéséért szavatolnak.

Kínában a 2008 és 2016 között felhalmozott rossz hitelkonstrukciók problémájának megoldása érdekében is alternatívát jelent a regionális bankokban szerzett állami tulajdonrészek további növelése.

Markáns ellenpélda ugyanakkor az Egyesült Államok gyakorlata 2010-et követôen, hiszen a Barack Obama elnök nevéhez köthető bankmentő jogszabálycsomag, az úgynevezett Troubled Assets Relief Program (TARP) által kivitelezett tőkeemelés nem szuverén alapok, hanem közvetlen állami tulajdonszerzés útján valósult meg. Ennek oka a demonstratív politikai célokban keresendő, mellyel a kormányzat a választói igényeket kívánta kiszolgálni azzal, hogy az államnak kiterjedtebb felügyeleti szerepkört biztosított a 2007-2009-es pénzügyi válságban érintett „rossz bankok” működését érintően.

Ezek után még a legenyhébb kifejezéssel élve is ironikus végkifejlet, hogy a kommunista Kína befektetési alapok útján, míg a pénzpiaci kapitalizmus hazája, az Egyesült Államok közvetlen állami tulajdonlás útján kívánta kézben tartani pénzügyi ágazatának egy részét.

30 A Norvég Szuverén Alap esetében ezt az elvet jól tükrözi a legnagyobb elérhető hozam elsődleges célként való kitǔzése. Lásd BACKER, Larry Catá: Sovereign Investing and Markets Based Transnational Rule of Law Building: The Norvegian Sovereign Fund in Global Markets. American University International Law Review, 2013/1, 30 . 
d) Az állam tulajdonában álló részvény (és más értékpapir)-portfóliók átrendezése és szuverén alapkezelés útján történő hasznositása szintén hozzájárulhat a szuverén alapok forrásainak bővüléséhez. Az ilyen eszközök közvetlen (például apport útján) vagy közvetett úton történő (privatizációs folyamatból vagy koncessziós szerződésből származó bevétel) átadása és hasznosítása hosszabb távon engedi érvényesülni a többletforrások nyújtotta előnyöket.

A szuverén alap ugyanis nemcsak rövid lejáratú eszközökbe fektetve tudja diverzifikálni tőkéjét, hanem hosszú lejáratú tulajdonosi jogokat megtestesítő (equity) típusú eszközökbe is. Ezzel a hozamlehetőségek köre is radikálisan bővülhet, ami azért előnyös, mert a kockázatok kerülése útján kezelt pénzpiaci eszközök hozama $^{31}$ nem minden esetben biztosít az inflációt meghaladó hozamot, miáltal a pénzügyi eszköztartalék értéke erodálódhat. Ilyen esetben a szuverén alap közbeiktatásának másik fontos előnye a diverzifikáció ${ }^{2}$ lehetősége, ugyanis ezzel nemcsak a nyilvános részvények, de a zártkörü kibocsátók értékpapírjai ${ }^{33}$ is elérhetővé válnak. Ezt a potenciális befektetési palettát tovább színesíthetik az alternatív befektetések is, mint például a nem saját kitermelésü, hanem a világpiacon vásárolt nyersanyagok, devizák, vagy az ilyen portfóliókon fennálló vagyoni jogok. ${ }^{34}$

\section{A szuverén alapok jogi státusza}

A szuverén alapok jogi helyzete a jegybankkal és az illetékes minisztériummal/ minisztériumokkal való kapcsolatból vezethető le. A valutatartalékot kezelő jegybank szerepe és az illetékes minisztérium (például gazdasági vagy pénzügyminisztérium) szerepvállalása a szuverén alapok müködtetésében lehet önálló, illetve együttes szerepvállalás, de az is előfordulhat, hogy a szuverén alap egyik szervtől sem függ és egyiknek sincs alárendelve. E konstelláció a szuverén alapok számára három müködési modellnek ad kereteket.

a) A legnagyobb önállóságot biztositó forma az elkülönült jogi személyiséggel rendelkező százszázalékos állami tulajdonban lévő részvénytársaság. Ebben az esetben az állam tulajdonosi jogait az illetékes tárcán (például a pénzügyminisztériu-

31 A pénzpiaci eszközök olyan pénzügyi instrumentumok, melyek lejárata egy éven belüli. A pénzpiaci eszközök piacát egészíti ki a tőkepiac, ami az éven túli lejáratú instrumentumok számára nyújt kereskedési felületet.

32 A diverzifikáció olyan eljárás, melynek során a kezelt vagyon több befektetési eszköz igénybevételével kerül megosztásra, csökkentve ezzel a portfólió rendszerszintű kockázatát. A diverzifikált befektetési portfólió nem garantálja a veszteségek elkerülését, de a kimagaslóan nagy kockázatot az átlagos - piaci, ágazati vagy más - rendszerszintü kockázati értékre csökkenti.

33 A zártkörü értékpapír-kibocsátás szabályai globális viszonylatban is minden esetben szűkebb befektetői körre szorítják az értékpapírjegyzést vagy -átvételt. Jellemzően a zártkörü kibocsátás természetétől függetlenül, limitált értéken és limitált befektetői részvétellel kerülhet sor ilyen kibocsátásra. A szükebb tulajdonosi vagy befektetői kör meghatározásával egyidejüleg csökken a potenciálisan allokálható források volumene, ugyanakkor kevesebb kötelezettség keletkezik a nyilvánosság irányában történő közzétételre.

34 Az alternatív befektetések köre gyakorlatilag a hagyományos részvény, kötvény, készpénzjellegű eszközökön kívül eső pénzügyi instrumentumok. Ebbe a kategóriába tartoznak a nyersanyagok, a devizák, a kereskedelmi célú ingatlanok, a fedezeti alapok (hedge fundok), a kockázati tőketársaságok és a műkincsek. 
mon) keresztül gyakorolja. A társaságot jellemzően az alapító ország a saját társasági joga alapján hozza létre. Az ilyen szuverén alapokra kínál példát a szingapúri szuverén alap, a szingapúri kormány befektetési részvénytársasága, amelyet GIC Private Limited (Government of Singapore Investment Corporation Private Limited) elnevezéssel hoztak létre, és amelynek a szingapúri állam az egyetlen tulajdonosa. ${ }^{35}$

b) A közjogi formában létrehozott és müködtetett szuverén alapok nem a polgári jog vagy az önálló társasági törvény rendelkezései szerint jönnek létre, hanem jellemzően külön jogszabály hozza létre öket, és valamely állami szerv hatáskörében vagy önálló állami szerv formájában müködnek. Ez a megoldás nem a fejlett országok általános gyakorlatát tükrözi, hanem a fejlődő országok szabályozási gyakorlatában - kimondottan az olajtermelő államok praxisában - realizálódik. Erre szolgáltat példát a Kuvaiti Befektetési Hatóság (Kuwait Investment Authority - KIA), melyet Kuvait 47. számú törvénye (The Law No. $47 .{ }^{36}$ ) hozott létre, illetve e törvény rendelkezései alapján folytatja müködését.

c) A szuverén alapok közjogi szervek alegységei is lehetnek, ilyenkor azonban csak az állam vagy jegybank egyes vagyontárgyait kezelik. Ebben a konstellációban minősül a legszükebbnek a mozgásterük, mert müködésük felett a jegybank és az illetékes minisztérium - a jogi szabályozástól függően - külön-külön vagy együttesen gyakorol közvetlen irányítási és felügyeleti jogköröket. Mivel elkülönült jogi személyiséggel az ilyen alapok nem rendelkeznek, a velük szemben érvényesített igények a jegybankkal vagy az állami szervekkel szemben fennálló igényeknek minősülnek. Másik részröl az állam vagy a jegybank rajtuk keresztül közvetlenül fektet be és kezel forrásokat. Az ilyen alapok ezért nem is minősülnek befektetési alapnak a szó szigorú értelmében, sokkal inkább a nemzetgazdasági források allokációjának szakapparátusi szerepét töltik be. Erre a megoldásra szolgáltat példát a norvég szuverén alap, a Norway's Government Pension Fund Global. ${ }^{37}$ A norvég szuverén alap vagyonkezelését a norvég jegybank vagyonkezelési részlege (Norges Bank Investment Management - NBIM) kezeli a norvég pénzügyminisztérium megbízásából.

A fentiek alapján körvonalazódik a szuverén alapok kettős jogállása. Az állam tulajdonosi szerepe ugyanis mindhárom esetben markánsan megjelenik, bár eltérő formában. Ugyanakkor jellemzően önálló jogalanyként az intézményi befektetők piacán is megjelennek a társasági formában müködő alapok vagy a közjogi alapkezelök. Nagyságrendjeik miatt és a befektetéseik stratégiai arculata okán, különösen érzékennyé válhat a kapcsolat az alapitó ország és a célország között a szuverén alapok müködése miatt. Emiatt fontos kitérni arra, hogy az úgynevezett szenzitív iparágakba történő befektetések esetén a célország ellenállhat, védekezési reakciói

35 A szingapúri kormány befektetési alapja, a GIC Private Limited (Government of Singapore Investment Corporation Private Limited) 1981-ben alakult a szingapúri kormány devizatartalékai kezelésére.

36 A törvény 1. cikkelye úgy fogalmaz, hogy egy független állami hatóság jön létre Kuvaiti Befektetési Hatóság néven, a pénzügyminisztériumhoz csatolva. A székhelye a kuvaiti állam, de külföldön is lehetnek irodái. Lásd www.kia.gov.kw/en/Pages/KIALaw.aspx (2016. 05. 16.).

37 A Norvég Jegybanki Vagyonkezelő (Norges Bank Investment Management - NBIM) a Norvég Jegybank vagyonkezeléssel foglalkozó szervezeti egysége, amely a norvég olajalapot a hivatalos nevén a The Government Pension Fund Globalt (GPFG) és a norvég valutatartalékok egy részét kezeli az 1998. évi megalakulása óta. 
pedig sokrétűek és erőteljesek lehetnek. Különösen érdekes, hogy éppen fejlett országok esetén vált kérdésessé az utóbbi tíz év gyakorlatában, hogy egyáltalán fel tudnak-e készülni az ilyen jellegü kihívásokra. Az Egyesült Államok stratégiai iparágait például meglepte és felkészületlenül érte, amikor Kína a 2007-2009-es pénzügyi válság után jelentős részesedéseket szerzett ezekben az ágazatokban. Befektetővédelmi38 és nemzetgazdasági érdekekre hivatkozva a fejlett országok különböző jogszabályokat ${ }^{39}$ alkottak ezeknek az ágazatoknak a védelmében.

Példaként szolgál az Egyesült Államokban tapasztalható megdöbbenésre a Foreign Investment and National Security Act of 2007 létrejötte, amely a külföldi befektetések nemzetbiztonsággal összefüggő kérdéseit szabályozta újra, a Defense Production Act of 1950 721. §-ának kiegészítésével. ${ }^{40}$ Ugyanis a korábbi szabályozás még az erre a célra létrehozott bizottság (Committtee on Foreign Investments - CFIUS) formális vizsgálata nélkül is engedélyezte külföldiek tulajdonszerzését bizonyos stratégiai ágazatokban. Ez történt a törvény megalkotását közvetlenül megelőző felvásárlási tranzakció esetében is. A Közel-Keleten kikötőket üzemeltető gazdasági társaság (a Dubai Ports International - DP World) ${ }^{41}$ ugyanis felvásárolta azt a - szintén kikötőket üzemeltető, angol nyilvánosan müködő - részvénytársaságot, ${ }^{42}$ mely az Egyesült Államok legfontosabb keleti partvidéki kikötői üzemeltetését látta el. Az Egyesült Államok lakosságának felháborodását követően azonban a DP World az Amerikában müködő kikötők üzemeltetési jogait egy egyesült államokbeli jogalany részére értékesítette.

A továbbiakban érdemes áttekinteni a szuverén alapokra vonatkozó nemzetközi ajánlási szintü szabályozást is. Ennek keretein belül ejtünk röviden szót az úgynevezett Santiago Elvek ${ }^{43}$ tartalmáról és azokról a célokról, melyeket előirányoznak.

\section{A Santiago Elvek}

A Szuverén Alapok Nemzetközi Munkacsoportja (International Working Group of Sovereign Funds - IWG) 2008. április 30. és május 1. között alakult meg az Egyesült Államokban, Washington D.C.-ben. Harmadik ülését a chilei Santiagóban tartotta, ahol a munkacsoportban képviselettel rendelkező 28 ország ${ }^{44}$ elfogadta azokat az

38 Lásd LeE, Yvonne C. L.: The Governance of Contemporary Sovereign Wealth Funds. Hastings Business Law Journal, 2010/1, 204.

39 LEE: i. m., 209.

40 LeE: i. m., 204.

41 A társaság tulajdonosa az Egyesült Arab Emírségek.

42 A The Peninsular and Oriental Steam Navigation Company számos, az USA keleti partján (New York, New Jersey, Philadelphia, Baltimore, New Orleans, Miami) működő kikötőt üzemeltet.

43 A Santiago Elvek (Santiago Principles) elnevezés a chilei fővárosról kapta a nevét, ahol a részt vevő szuverén alapok 2008. október 11-én elfogadták a Szuverén Vagyonalapok Általánosan Elfogadott Elvei és Gyakorlatai „Santiago Elvek” elnevezésű dokumentumot (Sovereign Wealth Funds Generally Accepted Practices and Rules „Santiago Principles”). https://www.imf.org/external/pubs/ft/survey/so/2008/new101508b.htm (2016. 06. 16.).

44 A munkacsoportban képviselettel rendelkező országok: Ausztrália, Azerbajdzsán, Bahrein, Botswana, Kanada, Chile, Kína, Egyenlítői Guinea, Irán, Írország, Dél-Korea, Kuvait, Líbia, Mexikó, Új-Zéland, Norvégia, 
elveket és gyakorlati szempontokat, melyeket a szuverén alapok müködésére nézve megfelelönek tartottak.

Az ajánlások $A$ szuverén alapok általánosan elfogadott elvei és gyakorlata, vagyis „Santiago Elvek" néven 2008 októberében került elfogadásra a munkacsoport által.

A Santiago Elvek 24 ajánlásból áll, melyek közül jogi szempontból az alábbit tartjuk fontosnak kiemelni:

A tizenhatodik ajánlás szerint a szuverén alapnak nyilvánosságra kell hoznia, hogy az alap vezetése milyen társaságirányítási modellben, milyen célokkal és milyen módon végzi - a tulajdonostól függetlenül - a munkáját. $A$ jól felépített felelős társaságirányításra jó példa a Koreai Investment Corporation (KIC) ${ }^{45} \mathrm{~A}$ KIC esetében kétszintü irányítási rendszerröl beszélhetünk. A legfelső döntéshozó szerv az Irányító Bizottság (Steering Committee). Az Irányító Bizottság kilenc föből áll. Hat külső tagot a Potenciális Civil Tagokat Jelölő Bizottság (Civil Member Candidate Nomination Committee) jelöl az üzleti szférából ${ }^{46}$ kétéves terminusra, mellettük a Stratégiai és Pénzügyminisztérium képviselöje, a Koreai Jegybank elnöke és a KIC első számú vezetője (CEO of KIC) tagjai még a bizottságnak. Az Irányító Bizottság hatáskörébe tartoznak a hosszú távú stratégiai és a legfontosabb gazdasági, jogi és személyi döntések. Ezenfelül az alapító okirat megváltoztatásától, a közép- és hoszszú távú befektetési politika meghatározásán keresztül a tőkeemelésekig, valamint a mérleg jóváhagyásáig terjed az Irányító Bizottság döntési hatásköre. A Befektetési és Kockázatkezelési Albizottság (Investment and Risk Management Subcommittee) a közép- és hosszú távú befektetési stratégiával összefüggésben támogatja az Irányító Bizottság munkáját. Az Irányító Bizottság munkáját két albizottság segíti, mégpedig a Tervezési Feladatokat Mérlegelő Albizottság (Budget Deliberation Subcommittee) a KIC müködtetéséhez járul hozzá, addig a Javadalmazási Albizottság (Compensation Subcommittee) a teljesítményértékeléshez nyújt támogatást.

\section{A szuverén alapok jogi helyzete Magyarországon}

Magyarországon az eddigiek szerint nem beszélhetünk szuverén alapokról és olyan speciális jogszabályról sem, amely kifejezetten szuverén alap formában müködő szervezet felállításáról rendelkezne és müködését szabályozná. Mindazonáltal a hazai gyakorlatban is megjelentek olyan vagyonkezelési formák, melyek a különb-

Katar, Oroszország, Szingapúr, Kelet-Timor, Trinidad és Tobago, Egyesült Arab Emirátusok és az Egyesült Államok. Állandó megfigyelöként vesznek részt a tanácskozásokon Omán, Szaúd-Arábia, Vietnam, a Nemzetközi Gazdasági Együttmüködés Szervezete (OECD) és a Világbank.

45 A Korean Investment Corporation (KIC), vagyis a Koreai Befektetési Részvénytársaság 2005-ben alakult azzal a céllal, hogy a Dél-Korea kormánya által rábízott vagyonelemeket kezelje az ország belföldi pénzügyi rendszerének fejlesztése érdekében, és hogy támogassa a hazai pénzügyi rendszer külföldi befektetéseit, valamint hogy ezen pénzintézetek részére külföldi társbefektetéseket (co-investment) tárjon fel.

${ }^{46}$ Azok jelölhetök tagként, akik legalább tízéves egyetemi kutatói múlttal vagy nemzetközi pénzügyi intézménynél szerzett - az elnöki rendelettel meghatározott idejü - gyakorlattal, vagy pénzügyi befektetési területen legalább tízéves ügyvédi vagy könyvvizsgálói gyakorlattal rendelkeznek, a Koreai Befektetési Részvénytársaságról szóló törvény, vagyis a Korea Investment Corporation Act (Act No. 7393) 11. §1. bekezdése szerint. 
ségek mellett is erös rokon vonásokat mutattak a szuverén alapokkal. llyenek voltak többek között a privatizációs szervezetek az 1990-es években (például ÁVÜ, ÁPV Rt.), a befektetési alapok (például OTP EMDA Származtatott alap és OTP Supra származtatott befektetési alap), az alternatív befektetési alapokat menedzselő társaságok (például Plotinus Nyrt.) és bizalmi vagyonkezeléssel foglalkozó társaságok (például Concorde Zrt.). Ezekben a jogintézményekben fellelhetők a szuverén alapok jellegzetességeinek egyes elemei.

\subsection{Az állami vagyon kezelése 2007-ig}

Az állami vagyon kezelésének új szemléletmódja az 1987 és 1990 közötti időszakra tehető „spontán privatizációval” összefüggésben merült fel. A folyamat az 1987. évi 28. tvr. hatálybalépésével indult, amely megengedte, ${ }^{47}$ hogy egy jogi személy részvétele esetén már magánszemélyek is részt vehettek rt.-k kft.-k, alapításában állami felügyelet mellett. Az önkormányzó vállalatok vezetése ugyanis tudatosan indította el az adott állami vállalat privatizációját az állam szemszögéből spontán módon, mivel az állam jogi eszközök hiányában beavatkozni már nem tudott. A folyamatot az 1989. évi XIII. törvény tette átláthatóvá az állam és a gazdaság többi szereplője által. A törvény 5 . § (1) bekezdése az átalakulás során ugyanis előírta a vagyonmérlegek készítését és annak külső és belső szervezetek általi jóváhagyását is. Ezzel az állami vagyon nagyobb védelmet kapott a spontán privatizációban történő szabályozatlan magánosításával szemben.

Az állami vagyon 1992-től két jól elhatárolható cél mentén került felosztásra. Egyrészt az állami tulajdonnak privatizáció során értékesítésre szánt elemei, amiről az időlegesen állami tulajdonban lévő vagyon értékesitéséről, hasznositásáról és védelméről szóló 1992. évi LIV. törvény rendelkezett. A törvény az Állami Vagyonügynökséget (ÁVÜ) ennek lebonyolítására hozta létre. ${ }^{48} \mathrm{~A}$ 1992. évi LIV. törvény 5 . §-a értelmében az ÁVÜ mint költségvetési szerv gyakorolta az állam tulajdonosi jogait. Tényleges vagyonkezelői tevékenységét az 1992. évi LIV. törvény 18. § (1) bekezdése alapján az Országgyülés által elfogadott Vagyonpolitikai Irányelve $k^{49}$ határozták meg. Érdemes megjegyezni, hogy az 1992. évi Vagyonpolitikai Irányelvek 3.2. pontja - igaz csak a privatizáció esetére vonatkoztatva, de - lehetőséget nyújtott az időleges állami tulajdonban lévő eszközök ${ }^{50}$ esetében a tulajdonosi jogok gyakorlója részére a befektetési alapokba, portfóliócsomagokba való áthelyezésre. Habár így csak az átmenetileg állami tulajdonban lévő vagyon esetében került sor vagyonkezelésre, de mégis például szolgált az önálló költségvetési szerv formájában elkülönült vagyonkezelési tevékenységre. $E$ tevékenységet - az 1992. évi CVI. törvény 8. § (1) bekezdés értelmében - a további szabályok éves szinten kapcsolták össze az adott évi költségvetéssel, ezért került sor együttes tárgyalásukra is. Az állami

\footnotetext{
47 Lásd http://mek.niif.hu/02100/02185/html/394.html (2016. 09. 20.).

48 1992. évi LIV. törvény II. fejezet.

49 71/1992. (XI. 6.) OGY határozat az 1992. évi Vagyonpolitikai Irányelvekről.

50 Ezek alatt az eszközök alatt az állam tulajdonosi részesedéseit értjük egyes társaságokban.
} 
vagyon másik része tartós állami tulajdonban maradt, amelyeket a tartósan állami tulajdonban maradó vállalkozói vagyon kezeléséről és hasznositásáról szóló 1992. évi LIII. törvény 1. § (2) bekezdése által létrehozott Állami Vagyonkezelő Rt. kezelésébe és hasznosítására adta.

Az 1995. évi XXIX. törvény az állami tulajdonban lévő vállalkozói vagyon értékesítéséröl nevével ellentétben nemcsak az időlegesen, hanem a tartósan állami tulajdonban maradó vagyonnal ${ }^{51}$ is foglalkozott. $E$ törvény 1 . $\S(3)$ bekezdése hozta létre az Állami Privatizációs és Vagyonkezelő Rt.-t (ÁPV Rt.). Az ÁPV Rt. az időleges vagyon értékesítése - azaz a privatizációs tevékenység és a tartós állami tulajdon vagyonhasznosítása - körében gyakorolta az állam tulajdonosi jogait.

\subsection{A nemzeti vagyon kezelésének jogi háttere}

A 2007. évi CIV. törvény az állami vagyonról két szempontból is érdekes. Egyrészt a törvény lezártnak tekintette az intézményes privatizációt, ${ }^{52}$ és így a szabályozás fö céljának a tartós vagyonkezelést rendelte. Ezért került sor az állami vagyon fogalmának újbóli meghatározására is, amelynek értelmében a törvény csak a tartósan állami kezelésben maradt vagyoni elemekre vonatkozott. Másrészt létrehozott egy újabb állami vagyonkezelő részvénytársaságot, a Magyar Nemzeti Vagyonkezelő Zrt.-t (MNV Zrt.)..$^{53}$

E törvény az állami vagyonnal való gazdálkodás új, korszerü szabályozását tűzte ki célul. Ennek keretében a 18. § az MNV Zrt.-t mint kizárólagosan állami tulajdonban lévő zártkörüen müködő részvénytársaságot definiálta, és annak vonatkozásában részletes müködési és szervezeti szabályokat állapított meg. Noha fogalmilag az állami vagyon kezeléséről rendelkezett e törvény, hiszen nevesítette is az állami tulajdonú társasági részesedéseket, mind a konkrét pénzügyi eszközöket. ${ }^{54}$ Mégis, tartalmát tekintve a jogszabály rendelkezései inkább a vagyon müködtetésére vonatkoztak, mint a szó szük értelmében vett kezelésre. ${ }^{55}$

A nemzeti vagyonról szóló 2011. évi CXCIV. törvény több újdonságot hozott. Egyrészt célként határozta meg „a jövő nemzedékek szükségleteinek biztosítását”. Másrészt a nemzeti vagyon köre tágabban került meghatározásra, hiszen a helyi önkormányzatok vagyonát is bevonta.

A törvény 3. § 19. pontja számos vagyonkezelő szervezetet nevesít. Ezek azonban - szinte - kivétel nélkül az állami vagyon kezelői voltak korábban is. Azért csak

51 1995. évi XXIX. törvény 7. §.

52 Az intézményes privatizáció tömeges és tervezett ütemben lebonyolított eljárások alapján ment végbe, ellentétben a spontán privatizáció 1989-1992 közötti időszakának gyakorlatával, ahol a folyamat ad hoc jelleggel folyt le - gyakran a meglévő jogszabályi keretek hézagainak kihasználása útján.

53 A 2007. évi CIV. törvény III. fejezete.

54 A 2007. évi CIV. törvény 1. § (2) bekezdés c) és e) pontok.

55 A vagyon működtetése és kezelése közötti különbség egyáltalán nem lényegtelen. Mindkét tevékenység portfóliószemléletben megy végbe, de míg a működtetés egy alapvetően passzív portfóliómenedzseri tevékenységre utal, addig a kezelés aktív tevékenység, melynek nélkülözhetetlen eleme a vagyoni elemek szűk határidőn belüli adásvétele és egymással történő felcserélése más jogcímeken. 
szinte, mert a törvény egy új vagyonkezelö formát is létrehozott a vagyonkezelő fogalmának meghatározásakor. Ugyanis a 2011. évi CXCIV. törvény 3. § 19. pontjának a g) alpontjában már lehetővé teszi a - törvény által - egyedileg kijelölt jogi személy bevonását is vagyonkezelői feladatokra. Ezzel megnyílt a lehetőség akár egy - csak részben állami tulajdonú, vagy akár teljes mértékben magántulajdonú - társaság megbízására vagyonkezelöi feladatok ellátására. Ez a szuverén alapok esetében számos esetben alkalmazott gyakorlatot teszi lehetővé, mégpedig a több egymástól független vagyonkezelő megbízását. A vagyon kezelése és hasznosítása ismételten az üzemeltetést és az értékmegőrző kezelést jelöli ki fő célul, de a törvény már nem tesz említést pénzügyi eszközökröl. Azonban a törvény a 16. §-ban nevesíti a speciális vagyonelemek külön törvényben meghatározott szabályok szerinti kezelését, például a jövő nemzedékek szükségleteinek biztosítása érdekében.

További lehetőségek állnak rendelkezésre a jegybanki és vagyonkezelöi tevékenységek jogi szabályozásának elemzése során. A befektetési vállalkozásokról és az árutőzsdei szolgáltatókról, valamint az általuk végezhető tevékenységek szabáIyairól szóló 2007. évi CXXXVIII. törvény 4. § 55. pontja ügyféltípustól függetlenül határozza meg a portfóliókezelés fogalmát. $E$ jogszabályban a magyar jegybank a 48. § (3) bekezdése szerint a szakmai ügyfél kategóriában a kiemelt intézmények között szerepel. Így a portfóliókezelésre jogosult személynek a jegybank mint kiemelt szakmai ügyfél e törvény rendelkezései szerint is adhatna megbízást. Ekkor azonban összeférhetetlenség állna fenn a két intézmény között, mert a jegybank a Magyar Nemzeti Bankról szóló 2013. évi CXXIX. törvény 4. § (9) bekezdése alapján ellátja a pénzügyi közvetítörendszer felügyeletét, így paradox módon a portfólió kezelésére jogosult személynek nemcsak megbízója, de felügyelője is lenne egy személyben. E jogszabály 4 . $\S(8)$ bekezdése mégis szabályozási mintát kínál a jogalkotónak azzal, hogy lehetővé teszi a magyar jegybank számára, hogy külön törvényben meghatározott jogkörében szanálási hatóságként ${ }^{56}$ járjon el.

\subsection{A nemzeti vagyon kezelésének lehetséges formája: a szuverén alap}

Az állami vagyon kezelésére vonatkozó jogszabályok fenti áttekintésével remekül illusztrálható az a tény, miszerint - bár meglehetősen rendszerezetlen formában, de - adott a lehetőség a szuverén alapok mint az állam pénzügyi eszközeinek kezelésére hivatott jogi konstrukciók létrehozására. Azonban ennek konzisztens jellegét erősítendő, a meglévő jogszabályok rendszerszemléletü kibővitésére és módositására lenne szükség. Mindez kevésbé égető szükségszerüség a szuverén alapok elindítása tekintetében, de annál sürgetöbb müködtetésük és kezelésük vonatkozásában, hisz a fentiekből egyértelmüen kiderül, hogy a magyar jogrendszer a szuverén alapkezelés e vonatkozásában tartalmazza a legtöbb deficitet.

56 A szanálási hatóság olyan döntési autoritást gyakorló pénzügyi intézmény, amely diszponálhat a nemzetgazdaság szempontjából kiemelt jelentőséggel bíró társaságok felszámolóinak kijelölése és a felszámolási folyamat lebonyolításának egyes kérdései tárgyában. 
A legfontosabb következtetés mégis az, hogy a fent említett jogi formák önmagukban talán alkalmasak, de semmiképpen sem ideálisak arra, hogy szuverén alap müködésének keretéül szolgáljanak. Ebböl a szempontból tehát célszerübb lenne egy célirányos jogi formát keletkeztetni. E speciális kérdéskörökben külön jogszabályi rendelkezésnek akkor is helye lenne, ha a szuverén alap egy - az állam kizárólagos tulajdonában lévő - gazdasági társaság formájában müködne. Ez a megoldás azonban kivételt képez nemzetközi viszonylatban is, hiszen az így müködő szuverén alap tekintetében sokkal nehezebb megjeleníteni az állami irányítás és ellenőrzés szempontrendszerét. Nem véletlen, hogy világszerte csupán egyetlen szuverén alap választotta a legegyszerübbnek tünő megoldást, mégpedig a fentiekben már többször hivatkozott szingapúri szuverén alap.

\section{Konklúzió}

A szuverén alapok állami tulajdonosi szempontjainak vizsgálata során felmerül a kérdés, hogy ezek a tulajdonosi érdekek milyen mértékben egyeztethetők össze a szuverén alapok intézményi befektetői szerepével a befektetési célországok érdekeinek és jogszabályi környezetének való megfelelés viszonylatában.

Megállapíthatjuk, hogy bár ezek a problémák első pillantásra váratlanul érték a fejlett célországok jogalkotóit, mégsem alakítottak ki egyértelmű jogszabályi tilalmat más országok szuverén alapjaival szemben. Ehelyett még mindig fenntartják a bizalmat a piac önszabályozó mechanizmusainak irányában, és a választ ajánlási formában a Santiago Elvek elfogadásával kívánták megadni a kihívásokra.

Mindezek alapján felmerül a kérdés, hogy érdemes lenne-e Magyarországon is létrehozni egy hasonló alapot? A válasz egyértelmüen igen. A forrás ugyanis rendelkezésre áll, mivel a jegybank a HUF-leértékelésből jelentős nyereséget származtatott. A szuverén alapok müködéséhez hasonló jellegzetességek már megfigyelhetök a jegybank jelen helyzetben alkalmazott befektetési politikájában is. ${ }^{57}$

Álláspontunk szerint mindez körültekintő szakmai előkészítő munkával és megfelelő jogalkotói szándékkal rövid vagy középtávon megvalósítható. Az elkülönült vagyonkezelő szervezet a devizatartalékok kezelésével együtt már USD milliárdokban értelmezhető indulóvagyonnal kezdhetné meg müködését. $A$ szuverén alapok ugyanis megfelelö prudens befektetési stratégiával, többszintü portfóliókezeléssel (Szingapúr GIC-alapjának gyakorlata), felelős társaságirányitással (Dél-Korea KICstruktúrája), kompetens szakemberekkel és külső vagyonkezelők bevonásával hoszszú távú értékteremtésre képesek. Ezzel hozzájárulhatnak a következő generációk jólétéhez és a hosszú távú nemzetstratégiai célok megvalósításához.

Ennek eszköze lehet a források becsatornázása a nemzetközi tökepiacok áramlásába, melyeken keresztül az egyes tőkepiaci jelenségeket - akár a recessziókat is - nyereség képzésére lehetne fordítani. Nem szabad azonban arról sem megfeledkezni, hogy figyelembe kell venni a célországok hatályos jogszabályai által kijelölt kereteket.

57 Lásd http://www.portfolio.hu/vallalatok/matolcsyek_beszalltak_a_teslaba_is.232565.html (2016. 05. 14.). 


\begin{abstract}
Sovereign funds are funds created and operated by the state. They came into the limelight after the financial crisis of 2007-08, when they saved the most emblematic listed companies in the US and Europe. The aim of the article is to explore some key issues related to sovereign funds. The paper discusses the origins of the term and some related economic concepts, including factors which resulted in the creation of sovereign funds. The legal background is also elaborated on both international and national levels, giving an insight into the regulatory framework. The article closes with propounding a sovereign fund in Hungary. This section gives an overview of state property management and its legal background.
\end{abstract}

